\title{
PAGAMENTO POR SERVIÇOS ECOSSISTÊMICOS E O DESENVOLVIMENTO SUSTENTÁVEL NA GUIANA FRANCESA
}

\author{
Maraluce Maria Custódio ${ }^{1}$ \\ Escola Superior Dom Helder Câmara (ESDHC)
}

Tania García López ${ }^{2}$

Universidad Veracruzana (UV)

Artigo recebido em: 04/11/2020.

Artigo aceito em: 26/02/2021.

\section{Resumo}

O presente trabalho busca entender se, e como, a Guiana Francesa pode usufruir dos pagamentos por Serviços Ecossistêmicos (SE) de maneira a proteger a região de floresta amazônica presente em seu território da exploração exacerbada, promovendo, ao mesmo tempo, um desenvolvimento sustentável que atenda a sua população, que, apesar de ostentar uma situação econômica melhor que as demais presentes na América Latina, não se aproxima da excelente condição dos compatriotas franceses do continente europeu. Tal estudo se realizará utilizando os métodos dedutivo e indutivo, com pesquisa bibliográfica e a consulta de sites específicos, buscando, por meio da análise da valoração econômica ambiental e dos preceitos de pagamento por serviços ecossistêmicos, compreen- der a situação histórico-geográfica e socioeconômica da Guiana francesa e demostrar que o pagamento por SEs pode, sim, auxiliar na independência econômica do departamento da Guiana em relação à França metropolitana e, ao mesmo tempo, evitar o crescimento desordenado e a exploração ilegal na região. Para tanto, se utilizará, por marco teórico, a teoria do desenvolvimento sustentável de Freitas (2011), a fim de concluir pela necessidade de efetivar os pagamentos por SE na Guiana Francesa como meio de garantir seu real desenvolvimento sustentável.

Palavras-chave: Amazônia.; desenvolvimento sustentável; Guiana Francesa; pagamento por serviços ecossistêmicos; valoração econômica ambiental.

1 Doutora em Geografia na Universidade Federal de Minas Gerais (UFMG), em programa de cotutela com a Université d'Avignon. Mestre em Direito pela UFMG e em Direito Ambiental pela Universidad International de Andalucía (UNIA). Graduada em Direito pela UFMG. Professora da graduação e professora permanente do Programa de Pós-Graduação em Direito da ESDHC (Mestrado e Doutorado em Direito Ambiental e Desenvolvimento Sustentável). ORCID: https:/orcid.org/0000-0003-2048-7883 / e-mail: maralucemc@gmail.com

2 Doutora em Direito pela Universidad de Alcalá de Henares, Madrid. Mestrado em Comunidades Europeias e licenciada em Direito pelo Centro de Estudios. Profissional especialista em e-learning 2.0 pela UNED. Fundadora e reitora da Escuela Jacobea de Posgrado, primeira universidade privada $100 \%$ on-line no México. Pesquisadora em regime de contratação integral na Universidad Veracruzana. Membro do Sistema Nacional de Investigadores del Consejo Nacional de Ciencia y Tecnología (CONACYT), México, nível I. ORCID: https:// orcid.org/0000-0002-9540-3691 / e-mail: tgar70@gmail.com 


\section{PAYMENT FOR ECOSYSTEM SERVICES AND SUSTAINABLE DEVELOPMENT IN FRENCH GULANA}

\section{Abstract}

This article search understand if and how French Guiana can use the payment of ecosystem services as a way to protect the part of the Amazon in its territory from exploitation in order to realize, at the same time, a sustainable development that serves its population. That despite having a better economic situation than other populations in Latin America, does not come close to the excellent condition of French compatriots on the European continent. Such study had use the deductive and inductive methods, with bibliographic technique, using the analysis of the environmental economic valuation, the precepts of payment for ecosystem services and understanding the historical geographic and socioeconomic situation of French Guiana to demonstrate that the payment by Ecosystem services can indeed assist in the economic independence of the department of Guyana from metropolitan France and at the same time prevent disorderly growth and illegal exploitation in the region. For theoretical framework the article uses the concept of sustainable development by Freitas (2011) and conclude the need to implement the PES in French Guiana as a way to guarantee a real sustainable development.

Keywords: Amazon; environmental economic valuation; French Guiana; payment for ecosystem services; sustainable development. 


\section{Introdução}

A França, a partir do departamento da Guiana, é um dos países pertencentes à regiấo de floresta amazônica, mas não participa de maneira inclusiva dos processos de estudo para proteçáo da totalidade da área. A Guiana ocupa uma parte pequena da Amazônia, menos de 2\%, mas ao mesmo tempo a Guiana é a Amazônia, já que esta ocupa $90 \%$ daquela. A Guiana ainda não percebeu sua feição de efetiva prestadora de SEs e, ao mesmo tempo, membro da comunidade amazônica que tem mais a acrescer na busca da implementaçáo do pagamento por SE, por ser parte da Uniáo Europeia.

O presente trabalho busca entender se, e como, a Guiana Francesa pode utilizar os pagamentos de serviços ecossistêmicos como meio de proteger da exploração, a parte da Amazônia em seu território. Considerando os preceitos ambientais, de maneira a realizar, ao mesmo tempo, um desenvolvimento sustentável que acolha sua população, que, apesar de ostentar uma situação econômica melhor que as presentes na América Latina, não se aproxima da excelente condição dos compatriotas franceses do continente europeu. Os métodos de pesquisa utilizados foram o dedutivo e indutivo, a pesquisa bibliográfica e a consulta de artigos científicos. Buscou-se, por meio da análise da valoração econômica ambiental, dos preceitos de pagamentos de SEs - compreendendo a situação histórico-geográfica e socioeconômica da Guiana francesa -, demostrar que o pagamento por esses serviços pode auxiliar na independência econômica do departamento da Guiana em relação à França metropolitana. Ao mesmo tempo, pode evitar o crescimento desordenado da mineração legal e ilegal na regiáo, bem como de atividades econômicas que desrespeitem ao meio ambiente, além disso, os SEs prestados pelo Departamento, beneficiam à regiâo, e por consequência, ao planeta, mas em especial à União Europeia, a que a Guiana faz parte legalmente.

Para tanto, se utilizará por marco teórico, a teoria do desenvolvimento sustentável de Freitas (2011), que, apesar de ser elaborada com base no Relatório Brundtland, primeiro a apresentar o conceito, foi desenvolvendo-se ao longo do tempo, atendendo as necessidades socioambientais para cumprir seu papel na proteção ao meio ambiente, tornando-se princípio basilar a partir da Convenção Rio 92. A teoria de Freitas (2011), entretanto, se apresenta mais adequada quanto ao desenvolvimento do tema.

Entre os vários conceitos que dão base ao desenvolvimento sustentável, Freitas, ao apresentar sua teoria, cumpre os preceitos estabelecidos pela Convenção Rio 92, de que o desenvolvimento sustentável - considerando o desenvolvimento econômico, a proteção ao meio ambiente e o desenvolvimento social -, deve ir 
além, ao defender uma reinterpretação das dimensôes apresentadas pelos elementos. Para realizar o desenvolvimento social, o autor acresce os enfoques ético e jurídico-político, para além do ambiental, social e econômico, atendendo, assim, o bem-estar social e não apenas o íntimo (FREITAS, 2011). Marco e Mezzaroba (2017) reiteram, ao acrescer que a idealização das dimensōes do desenvolvimento sustentável tem relaçáo com os deveres humanos, compromissos inerentes à cidadania.

A proposição do trabalho é de inserção da utilização do pagamento por SEs na agenda de políticas públicas, a serem implementadas no departamento da Guiana, pelo governo francês.

\section{Valor econômico dos ecossistemas e biodiversidade}

Os ecossistemas formam teias de vida complexas e são a base da constituição da natureza no planeta, neles ocorrem interações, em contínua evolução, entre os diversos seres vivos, entre si e entre o meio físico, entre estas, devemos considerar a ação dos seres humanos. As interaçôes rearranjam-se em função da necessidade adaptativa dos seres a mudanças, sejam estas negativas ou positivas. Segundo Andrade e Romeiro (2009, p. 4), os ecossistemas são como "sistemas adaptativos complexos, nos quais propriedades sistêmicas macroscópicas como estrutura, relação produtividade-diversidade e padróes de fluxos de nutrientes emergem de interaçôes entre os componentes, sendo comum a existência de efeitos de retroalimentação (feedback)".

A relação entre seres vivos e meio depende de como se dá a formação destes, idade dos elementos e distribuiçấo espacial, bem como o local no planeta em que se desenvolvem. Essa estrutura ecossistêmica, que é a base para os processos ecológicos, segundo Costanza et al. (1993), tem um grau de complexidade que varia de acordo com a quantidade de elementos e como eles se relacionam. Os autores lembram que sempre serão evolutivos, não se mantendo da mesma maneira, ou seja, não sendo mecanicista, nem lineares, impossibilitando, assim, prever quais e quando serão as mudanças no ecossistema. Tal constatação evidencia quão complexa é a teia da vida e que, para intervir pontualmente em um ecossistema, ou mesmo separadamente em seus elementos, é essencial compreendê-los. É necessário para uma real compreensão, analisar as interconexôes entre si, bem com os sistemas de entorno, pois:

Enquanto sistemas complexos, os ecossistemas apresentam várias características (ou propriedades), como variabilidade, resiliência, sensibilidade, persistência, confiabilidade etc. Dentre 
elas, as propriedades de variabilidade e resiliência apresentam importância crucial para uma análise integrada das interconexôes entre ecossistemas, sistema econômico e bem-estar humano (ANDRADE; ROMEIRO, 2009, p. 4).

Estes sempre serão condicionados pela localidade em que se desenvolvem, por causa da própria lógica de meio ambiente que aparece na Convenção de Estocolmo de 1972.

Os ecossistemas, suas relaçôes e elementos são essenciais para as atividades econômicas e para a existência humana, por isso, esses processos são reconhecidamente dependentes daqueles e são chamados de capital natural - ou ambiental. Mais que um insumo da produção econômica, este passa a ser visto como elemento essencial para a garantia da realização das atividades econômicas, inclusive em médio prazo, o que garantiria menos custos para a produção. $\mathrm{O}$ conceito de capital natural surge na década de 1970 e "pode ser considerado como o estoque de recursos naturais existentes que geram um fluxo de serviços tangíveis e intangíveis direta e indiretamente úteis aos seres humanos, conhecido como renda natural” (ARAÚJO, 2018, p 21). Ou seja, o capital natural alimenta as atividades econômicas e ao mesmo tempo recicla seus dejetos. Já Ferraz et al. (2019, p. 39) explica que:

[...] a partir de uma perspectiva ecológica, o capital natural não pode ser concebido apenas como um estoque ou agregação de elementos naturais, mas engloba todos os processos e interaçôes dos ecossistemas, que regulam e determinam sua integridade $\mathrm{e}$ equilíbrio ecológico (considera seu funcionamento). O capital natural nâo depende da construçấo humana para sua existência.

Logo, os humanos dependem dele para manutenção da vida como a compreendem, o que vem apresentando-se como paradigma na atualidade.

Para entender esse valor a TEEB (The Economics of Ecosystems and Biodiversity - A Economia dos Ecossistemas e a Biodiversidade), buscou calcular um valor econômico dos serviços prestados pela biodiversidade mundial, demonstrando em seus primeiros relatórios que esse valor chega inicialmente à ordem de 14 trilhóes de dólares (REPUBLIQUE FRANÇAISE, 2014). Este é um valor inicial, pensado o valor dos elementos materiais por si, que sáo base para produzir bens econômicos, e de serviços ecossistêmicos - ou ambientais ${ }^{3}$ prestados. Os Serviços Ecossistêmicos (SE), segundo (CAMPANHA et al., 2019), são aquelas coisas úteis que os ecossistemas fazem para as pessoas, fornecendo benefícios diretos e indiretos, tais

3 Neste trabalho, trataremos como se fossem a mesma coisa. 
como o oxigênio, a água e a regulação térmica, sendo intimamente ligados a geração de produtos e serviços como alimentos, energia etc. Porém, atualmente, o conceito mais utilizado é aquele adotado pela MEA (Millenium Ecosystem AssesmentAvaliação Ecossistêmica do Milênio), criado por Daily (1997, apud CAMPANHA et al., 2019, p. 40), um dos primeiros autores a conceituar de maneira atualizada os serviços ecossistêmicos, sendo "os serviços prestados pelos ecossistemas naturais e as espécies que os compóem, na sustentação e preenchimento das condiçóes para a permanência da vida humana na Terra".

A MEA foi proposta em 2000, pelo secretário-geral da ONU, Kofi Annan, que encomendou uma avaliaçáo do estado dos ecossistemas para mais de 1.300 pesquisadores de mais de 90 países. Realizada entre 2001 e 2005, buscou analisar as consequências das mudanças dos ecossistemas para o bem-estar humano e criar uma base científica para melhorar a conservação e o uso sustentável destes (CAMPANHA et al., 2019). A MEA vai contribuir para a inserção da SE nas agendas políticas dos países e a partir da publicação de seus estudos, vários outros projetos surgiram para contribuir para o reconhecimento da SE, tais como TEEB, IPBES (The Intergovernmental Science-Policy Platform on Biodiversity and Ecosystem Services - Plataforma Intergovernamental sobre Biodiversidade e Serviços de Ecossistemas), a ESP (Ecosiystem Sevice Partnership - Associação para Serviços Ecossistêmicos), entre outros.

Entre as várias categorizaçóes ${ }^{4}$ de SE, Andrade e Romeiro (2009) os categorizam como:

a) Serviços de abastecimento: alimentos, água, madeira, fibras, bioquímicos e material genético.

b) Serviços de regulação: climática, de doenças, biológica, de purificação da água, de danos materiais, de polinização.

c) Serviços culturais: ecoturismo e recreação, espiritual e religioso, estético e inspiração, senso de localização, herança cultural, paisagem.

d) Serviços de suporte; formação do solo, estoques de oxigênio e carbono, ciclagem de nutrientes e produçôes primárias.

Apesar de a categorização apresentada ser a mais didática, foi a categorização da MEA que criou uma classificação formal, que é utilizada amplamente. Esta divide os serviços ambientais em: serviços das espécies, serviços de regulação, serviços culturais e serviços de automanutenção. Essa abordagem enfatiza também a utilidade econômica e social dos elementos ambientais.

Assim, percebe-se que os serviços ambientais vão além dos elementos por si, pois devem ser tangíveis com o conforto térmico, a disposição e filtragem de

4 Vários grupos e programas realizam isso no mundo. Para mais informaçôes, vide Ferraz et al. (2019). 
água, entre outros elementos fundamentais para o desenvolvimento econômico sustentável. Sua existência é auferida por diversos indicadores, que possibilitam compreender os impactos ambientais positivos de cada ecossistema per se e o que se perde com sua destruição. É um estudo importante, pois fornece dados que cooperam e contribuem para a criação de políticas públicas de uso e proteção mais adequados às necessidades ambientais e não apenas econômicas.

A preservação desses serviços tem um custo alto, já que pode ser necessário restaurar, manter, preservar, não degradar, de modo que os ecossistemas efetivamente funcionem. As políticas tradicionais, principalmente na América Latina não atendem aos preceitos de preservação necessários. Apesar de ser, junto à África, um dos maiores - senão o maior continente detentor de ecossistemas que produzem serviços para a humanidade -, essas regióes, haja vista a necessidade de desenvolvimento e busca de crescimento constante do PIB (Produto Interno Bruto) por seus países, têm se preocupado mais com a questáo econômica que com a ambiental, e em alguns casos, com a social.

O SE, na perspectiva da economia, gera uma externalidade positiva, que deve ser considerada e valorada nas atividades econômicas. É uma externalidade importante para o bem comum global, já que efetiva a sadia qualidade de vida, gerando verdadeiros mercados, como exemplifica Mayrand e Paquin (2004).

Os mercados de serviços hidrográficos, em que a maioria das transaçóes ocorre em nível da bacia hidrográfica, como o fornecimento de águas para utilização nas terras da região e a produção de energia hidrelétrica, também requerem a regulação de fluxo, a preservação de habitats aquáticos, o controle da carga de salinidade da água, o controle de erosão, entre outras medidas de conservação.

Da mesma maneira, requerem regulamentaçáo os mercados de sequestro de carbono, que são globais e buscam transações para redução de custos de produção, baseados na emissão de carbono. Ou mesmo, o mercado de serviços da biodiversidade, que podem transitar do local ao global, e são extremamente complexos pois passam pelos serviços hidrológicos, de mercado de carbono e inserem uma gama enorme de atores que vão desde Organizaçôes não governamentais à indústria farmacêutica. Em suas transaçôes, fornecem serviços variados, desde a proteção de espécies à produtos comerciais inovadores que vão além, com os resultantes de bioprospecção, que às vezes são baseados no valor possível de descobertas futuras. Segundo (LAURAN; LEMÉNAGER; AOUBID, 2011, p. 11), estima-se "que os componentes "naturais" dos produtos cosméticos e perfumes representam US \$ 2,8 bilhões por ano. Estima-se que o mercado global de produtos fitossanitários derivados de material genético represente entre 0,6 e 3 bilhóes de dólares por ano" 
(tradução livre) $)^{5}$. Nesse contexto, é difícil, mas necessário, determinar o valor dos serviços e equilibrar oferta e demanda.

Por fim, existe o mercado de serviços paisagísticos, que de todos os mercados, segundo Mayrand e Paquin (2004), é ainda o menos desenvolvido, pois exige mecanismos de pagamentos mais sofisticados. Apesar de sua inserção local e global simultaneamente, o turismo é o que mais se beneficia desse mercado, pois demanda os serviços de beleza cênica, de elementos naturais relacionados com a cultura local, a proteção de locais de patrimônio natural, recifes de coral, santuários culturais ou mesmo meios de subsistência tradicionais. E, apesar de os governos serem os principais prestadores, há um aumento na prestação de serviços de preservação da beleza da paisagem pelas comunidades locais e pelos povos autóctones. Esse conceito também pretende incluir práticas culturais, usos tradicionais da terra ou características arquitetônicas, demonstrando a necessidade de preservação e seu alto valor agregado.

A visibilidade de todos os serviços ecossistêmicos, que como apresentado, criaram verdadeiros mercados, demostra a importância dos instrumentos econômicos e como favorecem a proteção ambiental.

Nesse contexto, fica aclarada, a necessidade de valorar o meio ambiente e seus serviços, demonstrando sua importância nas atividades humanas, especialmente para as atividades econômicas. Ao enfatizar a noção de função e serviço, a abordagem de SE, por meio do surgimento da Avaliação Ecossistêmica do Milênio, consagrou sua importância (MEA, 2005). Seu relatório é um marco importante na avaliação econômica dos SEs, pois em duas décadas de estudos destes, trouxe suporte para a tomada de decisóes relacionadas à conservação de inúmeros ecossistemas, que foram caracterizados e avaliados em termos monetários e inseridos no mercado como mecanismos de pagamento por SEs.

Tão difícil quanto valorar o meio ambiente é estabelecer o que é o valor ou valores a serem considerados. Tendo em vista que valores podem ser de diversos tipos: filosóficos, sociais, naturais, econômicos, religiosos, culturais etc. Valorar é algo complexo, porque é subjetivo. Cada sociedade vai valorar de acordo com suas experiências sociais, culturais e históricas, a depender também da função social do elemento e do bem-estar que este proporciona à comunidade (CUSTÓDIO, 2016).

Apesar de náo ser possível atender a todos os valores vinculados ao bem ambiental, ele tem que ser valorado de alguma maneira, para que não seja considerado desprovido de valor. Por isso, é necessária a inclusão da análise econômica na

5 "que les composantes 'naturelles' des produits cosmétiques et de parfumerie représenteraient 2,8 milliards USD par an. Le marché mondial des phytosanitaires dérivés de matériel génétique représenterait, quant à lui, entre 0,6 et 3 milliards USD par an". 
questẫo ambiental, dando início ao "desenvolvimento de métodos e técnicas de valoraçáo monetária dos impactos e danos produzidos pelo Ser Humano sobre o meio ambiente e consequentemente sobre a própria humanidade" (NOGUEIRA; MELLO, 2003, p. 17).

Apesar de, segundo Lauran, Leménager e Aoubid, (2011, p. 89), “o valor dos serviços de preservação da biodiversidade serem difíceis de definir e, a fortiori, de quantificar" (tradução livre) ${ }^{6}$, a valoração econômica exerce um papel importante nessa perspectiva, pois é com ela que se torna possível estabelecer valores econômicos tangíveis a valores outros, intangíveis dos ecossistemas. E tal valoração é realizada por meio dos chamados métodos de valoração econômica ambiental. Segundo Pearce (apud NOGUEIRA; MEDEIROS; ARRUDA, 2000), economistas não valoram o meio ambiente, e seus serviços, mas observam que indivíduos têm dado importância à preservação do meio ambiente, suas alteraçôes e seu uso consciente, o que gera preferências, as quais se estabelecem em diversos níveis de intensidade. Assim, o valor econômico desse bem pode ser estimado observando-se as preferências dos indivíduos pela preservação, conservação ou utilização, levando-se em conta a disponibilidade do recurso antes e depois da mudança gerada.

Em economia, tais preferências são interpretadas como a Disposição a Pagar (DAP) dos indivíduos por uma melhoria ou proteção de recurso ambiental, ou Disposiçáo a Receber Compensação (DAC) para aceitar uma piora ou modificação no ecossistema (ORTIZ, 2003). Ou seja, a economia não valora apenas reconhece os valores que lhe são apresentados e os converte em um valor econômico. Isto é feito por meio dos diversos tipos de métodos de valoração econômica. Segundo Santos e Custódio (2012), não existe uma classificação universalmente aceita dos métodos de valoração econômica. Neste trabalho será utilizada a classificação proposta por Bateman e Turner (apud NOGUEIRA; MELLO, 2003) que os dividem em:

a) Custo de viagem: método criado em 1947 e que analisa os gastos realizados por indivíduos em uma viagem a determinado local. Despesas estas que começam nos preparativos da viagem e terminam com o retorno dos viajantes. Passando pelos valores gastos em passagens ou combustíveis, lanches, hotéis, ou seja, todos os gastos para implementação da viagem. Ele tem como principais problemas para sua utilização a valoração do tempo e as viagens de múltiplos propósitos.

b) Preços hedônicos: um dos métodos mais antigos utilizados, surgido no século XIX. Ele se baseia na análise de valor dadas as características locacionais ambientais e paisagísticas, para a escolha de imóvel para compra ou aluguel. Essas

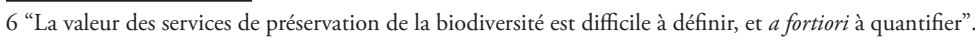


características levariam a um impacto imobiliário em determinados locais mais apreciados pelos indivíduos. O grande problema é separar claramente o impacto dos fatores ambientais e paisagísticos dos outros fatores.

c) Dose resposta: esse método analisa e quantifica o valor a partir de quanto se necessita para repor o bem degradado, utilizando preços aproximados presentes no mercado, bem como a análise de dados de outras áreas do conhecimento sobre o que foi degradado. Seu principal problema é o grande volume de dados de outras ciências, necessários para compor o quadro de valor de reposição, tornando o processo caro em termos monetários, além de ser limitado aos custos de reposição e acreditar que a reposição sanaria os danos causados, fato impossível em muitos casos, como, por exemplo, a perda da paisagem.

d) Custos evitados: esse método utiliza-se dos valores gastos em produtos substitutos ou complementares para tornar utilizável o bem, ou para melhor adequação à mudança gerada no meio ambiente, mensurando monetariamente a percepção dos indivíduos.

e) Método de valoraçáo contingente: ele foi proposto em 1963 e é muito utilizado para análise de valores ligados à recreação. Ele parte do pressuposto de que as pessoas têm graus diferentes de preferências por diferentes bens, estas se expressam quando compram ou pagam por algo e isso é mensurado pelo DAP (disposiçãoo a pagar) ou pelo DAC (disposição a receber compensação). A valoração ocorre a partir da observação dessas preferências do consumidor em situaçôes hipotéticas, apresentadas por meio de questionários. É um método muito utilizado, por ser o único que avalia o valor de existência de um bem, mesmo que este jamais seja utilizado. Tem como problema principal os custos, pois, necessita de no mínimo 1000 observaçóes para iniciar a análise.

Esses métodos de valoração econômica também são utilizados para avaliar o pagamento por serviços ecossistêmicos, pois, apesar de o SE apresentar benefícios intangíveis, estes devem ser reconhecidos para serem protegidos e valorados economicamente, o que torna evidente sua importância num mercado capitalista. Como defende Ferraz et al. (2019, p. 43) "a valoração econômica não significa privatização ou "comodificaçâo" dos SE, uma vez que eles podem ser bens públicos ou comuns. Dar valor econômico apenas norteia a materialidade de valores intangíveis, considerados pela sociedade.

$\mathrm{O}$ pagamento por $\mathrm{SEs}^{7}$ é um instrumento econômico baseado na utilização dos métodos econômicos de valoração e, segundo Ferraz et al. (2019, p. 44):

7 Neste trabalho, a expressăo "pagamento por serviços ecossistêmicos" será utilizada como sinônimo de "pagamento por serviços ambientais". Porém, segundo Gaudereto et al. (2018), existe, ainda, uma discussão do conceito apropriado a ser utilizado: pagamento por serviços ambientais (SA) ou pagamento por serviços ecossistêmicos (SE), que vários autores tratam como termos que designam o mesmo objeto (ELOY; COUDEL;TONI, 2013) e outros como diferentes (SOUZA et al., 2016). Inicialmente os trataremos como significados. 
De uma forma mais restrita, PSA se refere a um instrumento baseado no mercado para financiar a conservação e que considera os princípios do usuário-pagador e provedor-recebedor, pelos quais, por meio de uma transação voluntária, aqueles que se beneficiam dos serviços ambientais podem pagar por eles, e aqueles que contribuem para a geração desses serviços devem ser compensados por proporcioná-los.

O pagamento por SEs é um dos modelos de incentivo à conservação, que dá visibilidade àqueles elementos que mantêm a produção de SEs e os conecta aos que deles se beneficiam, e principalmente, elucidam sobre a relevância dos princípios do poluidor-pagador e recebedor-protetor, como demonstrado por Pagiola, Von Glehn e Taffarello (2013).

Os princípios ambientais são a base da proteção ambiental, sendo centrais os princípios da precaução e da prevenção, que não se confundem. Como explicam Costa e Oliveira (2019, p. 30):

O princípio da precaução atua de modo a exigir a prudência do Estado, da sociedade civil e da iniciativa privada em relaçáo a qualquer atividade humana, que, diante de incertezas científicas ou técnicas, possa gerar dúvida acerca de sua potencialidade para causar risco ao meio ambiente. Não há, pois, que se equivocar na identificação do princípio da precaução com o da prevenção, uma vez que este tem por diretriz prevenir impactos já conhecidos enquanto o anterior atua como alerta frente ao perigo ignorado.

Inicialmente, os instrumentos econômicos eram utilizados para a prevençáo nas políticas para conservação dos ecossistemas, prevenindo as externalidades negativas, como por exemplo, as taxas verdes. Segundo Mayrand e Paquin (2004, p. 1) "na última década, novas abordagens enfocaram a criação de externalidades ambientais positivas por meio da adoção de incentivos econômicos adequados, muitas vezes na forma de subsídios ou outros programas ambientais, por exemplo programas agroambientais" (tradução livre) ${ }^{8}$.

As externalidades positivas dão mais argumentos, e demonstram as vantagens de aplicação dos pagamentos por SEs. A vida humana, entretanto, por sua existência já desconectada dos ciclos naturais ambientais, nos quais os outros seres vivos estão inseridos, depende de uso maior da natureza para manter a existência desejada. A produção tecnológica cada vez mais desconecta os seres humanos dos ciclos

8 "Mais au cours des dix dernières années, de nouvelles approches mettent l'accent sur la création d'externalités environnementales positives par l'adoption de mesures d'encouragement économiques adéquates, souvent sous forme de subventions ou d'autres programmes environnementaux, par exemple les programmes agro-environnementaux". 
naturais a que compóem, e o uso humano do capital natural é cada vez maior ao longo da história. Esse uso não deve ser gratuito, por isso a necessidade de se pagar pelos serviços ecossistêmicos.

O SE não se compôe apenas dos serviços da natureza, mas também de serviços culturais e sociais, pois a alteração destes prejudica o bem-estar e a saúde ambiental, já que destrói interaçóes que organizam o meio ambiente em âmbito global, e por isso, todos devem ser considerados nos pagamentos por SEs.

Segundo Lauran, Leménager e Aoubid, (2011) as situaçôes mais difíceis para se realizar pagamentos por SEs são relacionadas a bens públicos, porque a visibilidade dos SE é dificultada pela extensão das externalidades positivas que geram (oxigênio, conforto climático), fatores notados apenas quando faltam. Já no microssistema dos bens privados, o detentor já percebe a variação e sua exploração é regulada e fiscalizada de modo mais substancial, facilitando os pagamentos por SEs. Isso porque, no privado a atividade é condicionada, ao passo que, no público - por ser público -, é visto como algo de todos, além de ter uma área muito maior, ou seja, dificultando sua visibilidade e a fiscalizaçáo das atividades.

\subsection{Pagamento por serviços ambientais}

O preceito de que os seres humanos se beneficiam e dependem da natureza é incontestável, mas não é desde sempre que ela é reconhecida como conectada e interdependente com aqueles. Inicialmente, a natureza era vista como renovável e abundante, também era vista como um insumo a ser trabalhado para produzir bens. Imperfeita, deveria ser melhorada pelos seres humanos para ter um valor em todos os sentidos e não apenas econômico. Seu reconhecimento como essencial, inclusive para a existência humana, se inicia com os movimentos da década de 1960, que conduziriam à Convenção de Estocolmo de 1972, que incentivou a era das legislaçóes nacionais de proteção ao meio ambiente.

Segundo Campanha et al. (2019), a economia ecológica surge na década de 1990, especialmente a partir do momento em que é demonstrado que é possível estimar valor monetário para os serviços ambientais. Para e Campanha et al.(2019, p. 43):

[...] valoração econômica não significa privatização ou "comodificação" dos SE, uma vez que eles são tratados como bens públicos ou comuns. Ao contrário, trata-se de ferramenta importante para nortear agências públicas, na priorização de investimentos em açôes de preservação, conservação, recuperação e manutenção dos SE. 
A atividade econômica, poluidora, como bem apresenta Poffo (2002, p. 257), vem apropriando os "direitos da sociedade, pois os poluentes representam um confisco do direito de alguém respirar ar puro, beber água saudável e viver com tranquilidade" em troca dos lucros de poucos.

As novas correntes da economia, especialmente a economia ambiental, têm modificado a visão do meio ambiente, visto inicialmente apenas como insumo. $\mathrm{E}$ cada vez mais demonstra o quanto se perde com os danos ambientais em termos de lucros sociais, numa visão macro ambiental e mesmo numa visão micro ambiental, e o quanto se pode lucrar com a preservação e redução de poluentes em vários campos da indústria e outras áreas.

Neste ponto, entra a economia, que desempenha o importante papel de pensar a mudança da realidade, tentando aliar o desenvolvimento racional com a preservação ambiental. Esta trabalha no sentido de prevenir o dano, pois este é muito menos lucrativo em longo prazo, demonstrando como preservar pode gerar mais lucros do que destruir.

Esse distanciamento entre ambos - economia e meio ambiente -, gera a crise ambiental, na qual os processos econômicos estão sujeitos a uma lógica de mercado perversa, que não contabiliza a degradaçấo ambiental como externalidade negativa e relevante na tomada de decisóes. É necessária uma reforma na visão dessa lógica de mercado, pois as externalidades sociais e ecológicas se ampliam cada vez mais, em função da irracionalidade (ou excessiva racionalidade) do capital, o que poderá gerar a ampliação da crise ambiental, bem como a insustentabilidade do próprio mercado.

A partir da compreensão da existência desse capital, surge a ideia de prestação de serviços ecossistêmicos. Segundo Campanha et al. (2019), a Prestaçáo por serviços ecossistêmicos começa a ser reconhecida em 1977, denominada inicialmente de serviços da natureza por Westman, que sugere que os benefícios gerados aos seres humanos pela natureza poderiam ser dimensionados de modo que a sociedade poderia decidir como geri-los e como utilizá-los. Serão, entretanto, Erlich e Erlich, em 1981, que proporão o termo Serviços Ecossistêmicos, buscando estimular o interesse social pela biodiversidade, já num contexto de vislumbre da importância da natureza e de compreensão de meio ambiente.

Com o sucesso em termos de políticas públicas pensadas para o meio ambiente, a partir da Convenção Rio 92, os SEs passam a fazer parte dos debates públicos sobre a proteção ao meio ambiente. Para Lauran, Leménager e Aoubid, (2011, p. 24, tradução livre), o pagamento por SE é um

[...] "instrumento económico", ou seja, um dispositivo que visa produzir um efeito, através do próprio pagamento, no 
comportamento de um agente. É uma questão de manter esses comportamentos (por exemplo, a criação extensiva), ou de fazêlos evoluir (por exemplo, pagar aos aldeóes para que parem de caçar, ou aos agricultores para que não poluam mais; pagar pela conversão de um agricultor em orgânico, um engenheiro florestal para trabalhar de maneira diferente, um agricultor de cacau para cultivar sob cobertura florestal, etc.). ${ }^{9}$

Sendo assim, o pagamento por SEs surge como instrumento econômico para a conservaçáo ambiental, baseando-se no mercado para financiar a conservaçáo, já que o meio ambiente é substrato, que fornece a garantia de que as atividades e os serviços sejam executados em processo contínuo. Tendo como fundamento os princípios do usuário-pagador que, segundo Silva (2015, p. 77), "estabelece que o usuário de recursos naturais deve pagar por sua utilização. A ideia é de definição de valor econômico ao bem natural com intuito de racionalizar seu uso e evitar seu desperdício", em que o protetor-recebedor teria o objetivo de

[...] evitar que o 'custo zero' dos serviços e recursos naturais acabe por conduzir o sistema de mercado à hiperexploração do meio ambiente, e se esteia na ideia fundamental de que não basta punir as condutas ambientalmente danosas para preservar com eficácia o meio ambiente, sendo mais produtivo recompensar as virtuosas. Ou seja, ao invés de coibir a geração de externalidades negativas no processo produtivo, incentivar-se-iam as positivas por meio de normas promocionais (MILARÉ, 2015, p. 271).

Apesar de otimistas verem o pagamento por SEs como solução para crise ambiental, é visível que ele apenas é um dos instrumentos econômicos eficazes para a proteçáo do meio ambiente, mas não a solução definitiva. Nesse contexto, pensado a partir da economia, a escassez é um fundamento para inserçáo do valor econômico e para a instituição do pagamento por SEs. Por isso, faz-se necessária uma análise sobre o que seria essa escassez dos ecossistemas, pois considerando friamente, estes estão sendo destruídos, ou realmente entraram em escassez? Faz-se necessário analisar a questão da escassez em face do preceito de necessidade, tanto para um contexto presente, quanto futuro, pois é a necessidade de implementação dos SEs, mais que a escassez presente e futura, , que fundamenta a proteção ao meio ambiente. Sempre tendo em mente que os estudos ambientais trabalham

9 "[...] instrument économique, i.e. un dispositif qui vise à produire un effet, par le paiement lui-même, sur le comportement d'un agent. Il s'agit soit de maintenir ces comportements (par exemple, l'élevage extensif), soit de les faire évoluer (par exemple, rémunérer des villageois pour qu'ils cessent le braconnage, ou des cultivateurs pour qu'ils ne polluent plus; payer la reconversion d'un cultivateur en bio, un forestier pour qu'il exploite différemment, un planteur de cacao pour qu'il cultive sous couvert forestier, etc.)". 
não apenas com as geraçóes presentes, mas também com projeçóes futuras.

A questão não é o pagamento pela destruição que se realizará, mas compreender que esse meio ambiente é único e uma vez devastado, não cumprirá seu papel para as geraçóes presentes e, muito menos, para as futuras. $\mathrm{O}$ meio ambiente é necessário e pode não estar escasso ainda, ou mesmo, o meio ambiente recuperado, que demanda tempo para chegar ao ponto de desenvolvimento que o original destruído, o que representa um desequilíbrio.

O meio ambiente não é um ativo facilmente substituível, como uma máquina, logo, por isso, há de se repensar sua função, mas também sua existência única, percebida em cada ecossistema. O grande argumento de valorar e estabelecer uma métrica econômica de pagamentos por SE é exatamente a escassez, pois, cada ecossistema cumpre um papel ou função diferente e talvez única. Atualmente, sua definição de importância é feita politicamente e não socialmente, sendo este um problema à parte na valoração, que também deve ser observado, pois interfere na determinação do valor estabelecido.

Por isso Lauran, Leménager e Aoubid, (2011) garantem que ao aplicar o pagamento por SE, há grandes vantagens, sendo as principais:

1. Ao fazer da preservação do meio ambiente uma atividade remunerada, os agentes econômicos e as comunidades locais se interessariam em garanti-la.

2. Uma prestação por serviços ecossistêmicos também possibilitaria a mobilização de recursos financeiros para pagar pelos SEs de atores que se beneficiam destes.

3. A PSE estabelece uma relação contratual entre agentes econômicos que concordam em pagar por práticas que garantam a manutenção ou restauração do SE, encurtando as relaçóes. Nesse cenário, não haveria intermediários, e as partes estariam mais próximas do problema, o que favorece soluçóes práticas e funcionais adaptadas a cada situaçáo local.

O sistema de monetarização por SE não é perfeito, mas garante a busca de compreensão racional da economia em relação ao meio ambiente em sentido amplo, garantindo sua proteção. Santos (2018), apresenta algumas críticas à aplicação do pagamento por SEs, tais como: ser antropocêntrico, conflitar com os objetivos de conservaçáo da biodiversidade, se preocupar mais com a avaliaçáo econômica do que com o meio ambiente em si, promover a mercantilização da natureza, não ter conceitos e classificaçóes precisos, não compreender que todos os processos ecossistêmicos são importantes, os preceitos para regulação serem econômicos e não éticos, pois estes atenderiam ao mercado economia e seu autointeresse.

Santos (2018), também defende a aplicação de pagamentos por SE, alegando que vai além de valores puramente econômicos, englobando outros tipos. 
Defende, ainda, que ele é também pedagógico e conduz o interesse dos atores para a conservaçáo da biodiversidade, além de reconectar a sociedade com os ecossistemas, o que incentiva a conservação da biodiversidade. Por fim, alega que o fato de não apresentar termos precisos, melhora a colaboração transdisciplinar de valoração, o que gera uma obrigaçáo ética e sentimento moral.

Segundo Mayrand e Paquin (2004), desde 1961, os países tropicais perderam mais de 500 milhóes de hectares de cobertura florestais, o que conduziu e ainda conduz à perda de SEs importantes para subsistência, desenvolvimento econômico e saúde da população mundial.

O grande problema que se evidencia é que, apesar de toda a informação e a tecnologia atuais, os SEs são pouco conhecidos, mal-entendidos ou simplesmente esquecidos por todos os grupos que deles se utilizam, e não estão internalizados nos processos. Os pagamentos por SEs buscam cobrir essa lacuna e internalizar os custos gerados ao meio ambiente, por meio de medidas para valorá-lo. Encorajar o pagamento de SEs é uma medida para desanuviar os déficits gerados e apresentar um valor, considerando os custos diversos dos recursos que são viabilizados para a produção econômica e para a sociedade mundial. A Amazônia tem um papel essencial para a ordem natural do planeta e seus serviços náo têm sido compensados adequadamente.

\section{A Amazônia e seus serviços ambientais}

Segundo a Organização das Naçóes Unidas (ONU), as florestas cobrem um terço de todo o planeta e abrigam $80 \%$ de sua biodiversidade. Nesse contexto, a Amazônia é uma área de 7 milhóes de quilômetros quadrados, dos quais 5,5 quilômetros são de floresta tropical latifoliada úmida, e o restante contempla outros ecossistemas tais como matas e cerrado. Seu território trespassa nove países, sendo que $60 \%$ da área está em território brasileiro, além de Peru, Equador, Colômbia, Venezuela, Bolívia, Guiana, Suriname e França (departamento de Guiana Francesa). Para se ter noçáo de sua magnitude, a floresta ocupa dois quintos da América do Sul e 5\% da superfície terrestre, o que representa mais da metade das áreas de florestas tropicais no mundo. $\mathrm{Na}$ atualidade, ela abriga uma rede hidrográfica que escoa um quinto do volume de água doce do mundo, conhecida como Amazônia Azul. Sua grande área abriga uma diversidade de florestas, dadas as diferentes características geológicas de seu território. Abriga também várias espécies das quais apenas 1,8 milhão foram descritas e, estima-se que ainda tenham entre 10 e 100 milhóes a serem descobertas. Ela se configura como uma importante área de endemismo. Além da diversidade cultural, pois a Amazônia 
abriga 420 povos indígenas, 86 línguas e 650 dialetos (PNUMA;OTCA; CIUP, 2008).

Com toda essa magnitude, a Amazônia fornece inumeráveis benefícios ecológicos e socioecológicos para a humanidade. Somente sua existência fixa mais de uma centena de trilhóes de toneladas de carbono, garantindo a não emissão deste para a atmosfera, o que agilizaria as modificaçôes climáticas, além disso, contém paisagens magníficas, além de proteger inúmeras espécies de toda a ordem de seres vivos, de ser uma grande fonte de água doce e de proteger populaçóes humanas, principalmente as tradicionais e todas as culturas construídas em torno dessas existências (IDSM, [s.d.]). A Amazônia beneficia, com seus serviços ecossistêmicos, direta e indiretamente, toda a humanidade, para além das comunidades locais. Segundo Kitamura (1997, p. 289):

Além disso, a Floresta Amazônica tem também um valor ontológico (valor de existência para os neoclássicos), ou seja, intrínseco (intangível) para a sociedade - por motivos altruístas (culturais, religiosos, estéticos, éticos, etc.) - simplesmente pelo fato de existir, independentemente de seu uso corrente.

E para as comunidades locais, os chamados povos da Amazônia, o valor desta é visível no dia a dia, pois é esse bioma que lhes garante alimentação, moradia e meios de subsistir economicamente, "além disso, a Floresta Amazônica fornece uma infinidade de produtos para consumo próprio ou para a venda, como madeiras, peles, fibras, resinas, gomas, óleos, corantes, aromáticos, taninos, medicamentos, etc." (KITAMURA, 1997, p 283). Sua utilização de maneira direta é dada pela visitação e observação, camping, vivências, caminhadas, cenário de filmagens, de reportagens fotográficas, ecoturismo e outros.

O ecoturismo tem representado uma fonte de renda importante em países como Costa Rica, Quênia e Tanzânia (KITAMURA,1997) e o uso ordenado e bem programado da Amazônia, pelos países a ela pertencentes pode gerar lucros importantes, espelhando-se nos exemplos citados, propiciando o desenvolvimento sustentável e uma maneira menos impactante de utilizar os recursos da regiáo, quando comparada às atualmente predominantes, como a agropecuária extensiva. Além disso, há a possibilidade de manter a cultura secular de uso e manejo da floresta como fonte de renda, o que é compatível com a preservação da área e com a garantia de seus SEs.

O não reconhecimento e a não divulgação, e o desconhecimento dos SEs da Amazônia têm conduzido à perda e destruição de diversos componentes desta, o que representa risco para todo o ecossistema e para a própria vida no planeta. Estes são causados, por exemplo, pelo aumento da exploração ilegal de madeira, 
de terras e de florestas em áreas destinadas à agropecuária, com o maior uso de agrotóxicos, ou com a instalação de hidrelétricas e consequente formação de lagos imensos, que modificam profundamente o equilíbrio dos ecossistemas aquáticos e alteram hábitos das populaçôes tradicionais; implantação e ampliação da atividade industrial e mineral, com aumento significativo na poluição do ar e na produção de resíduos e efluentes, que chegam aos corpos hídricos, modificando suas características naturais e provocando danos ambientais e à saúde (KITAMURA, 1997).

A defesa do não uso da floresta é uma falácia, mas o uso desregrado e feito sem o devido planejamento e compreensão dos sistemas ambientais pode conduzir a uma série de prejuízos, perdas de biomas, com impactos locais, regionais e mundiais. Segundo Marengo (2006), a perda da biodiversidade, que acelera e poderá ser acelerada pelas mudanças climáticas, seria um prejuízo para a humanidade, e o aquecimento global afetaria o planeta todo. Além disso, segundo Mayrand e Paquin (2004), deve-se levar em conta que os fluxos intra e inter-regionais de umidade atmosférica, se reduzidos, poderiam implicar a escassez de água para o consumo humano, e para a agricultura - irrigada ou não -, e na reduçáo de geração de energia hidrelétrica nos países pertencentes à Amazônia. Um exemplo disto é o cerrado brasileiro, que não sobrevive sem a água da Amazônia, assim como os rios amazônicos dependem da água proveniente do Planalto Central.

Assim, a análise dos SEs e os impactos ambientais devem ser abrangentes para compreender as interconexôes. Para se ter dimensão da questão, uma árvore grande pode bombear do solo e transpirar mais de mil litros de água num único dia, a Amazônia detém centenas de bilhóes de árvores em suas florestas, que transpiram vinte bilhôes de toneladas de água por dia, jorrado para o ar num rio vertical de vapor, mais importante que o Amazonas. Aspecto que demonstra o quanto o patrimônio da região amazônica é uma incógnita, elucidando que a preocupação com o desmatamento e uso desmedido e não planejado feito dela é urgente.

A Amazônia está vivendo um processo de degradação ambiental que se evidencia no aumento do desmatamento, na perda da biodiversidade, na contaminação da água, na fragilização dos valores e modos de vida dos povos indígenas, na deterioraçáo da qualidade ambiental nas áreas urbanas. Essa situação é resultado de um conjunto de processos e forças motrizes que afetam de maneira negativa seu complexo ecossistema e os serviços proporcionados por este, e que se traduzem em perdas na qualidade de vida para a população local, nacional e de toda a regiāo (PNUMA; OTCA; CIUP, 2008, p. 14). 
A maneira como o desenvolvimento está sendo realizado na Amazônia não atende aos preceitos do conceito de desenvolvimento sustentável, utilizados como marco teórico do presente trabalho (FREITAS, 2011).

A grande questão é que, mesmo com a instalação de empreendimentos em grande escala, não é apresentada uma melhora de infraestrutura ou na garantia de direitos sociais aos residentes da regiáo. Essas atividades têm destruído a floresta Amazônica, e desconsiderado o desenvolvimento econômico em termos do benefício que poderia ser gerado com a implementação de um sistema de pagamentos por SEs - cumprindo os preceitos de racionalidade extrativista e da coordenação e planejamento de uso. Infelizmente, o uso desse recurso é muito pequeno, logo, náo atende a nenhum dos elementos do desenvolvimento sustentável apresentado por Freitas (2011).

Faz-se urgente criar medidas pensadas de maneira a visualizar e atentar para os SEs que a Amazônia realiza e valorá-los de maneira a garantir seu uso e manter seus serviços em pleno funcionamento, sob pena de ameaça ao modo de vida humano em todo o planeta.

O Quadro 1 apresenta alguns elementos a serem valorados e a maneira de melhor realizar tal valoração.

Quadro 1 - Valor econômico da Floresta Amazônica

\begin{tabular}{|c|c|}
\hline Tipo & Valor percebido \\
\hline $\begin{array}{l}\text { Valor de uso direto (+ tangível) } \\
\text { Direto } \\
\text { Indireto }\end{array}$ & $\begin{array}{l}\text { Para consumo direto como: } \\
\text { - rede de subsistência; } \\
\text { - produtos para venda; } \\
\text { - matéria-prima industrial; } \\
\text { - genes para cultivo; } \\
\text { - ecoturismo/lazer etc. } \\
\text { Para consumo indireto como: } \\
\text { - regulador climático; } \\
\text { - mantenedor dos ciclos bioquímicos; } \\
\text { - mantenedor do equilíbrio dos ecossistemas. }\end{array}$ \\
\hline $\begin{array}{l}\text { Valor de opção } \\
\text { Valor de existência (- tangível) }\end{array}$ & $\begin{array}{l}\text { Para consumo futuro: } \\
\text { - disposiçáo a pagar para opção de consumo futuro. } \\
\text { Náo relacionado ao consumo: } \\
\text { - motivos culturais; } \\
\text { - motivos estéticos; } \\
\text { - motivos éticos etc. }\end{array}$ \\
\hline $\begin{array}{l}\text { Valor econômico total = valor de uso }+ \text { de } \\
\text { opção + de existência. }\end{array}$ & \\
\hline
\end{tabular}

Fonte: adaptado de Kitamura (1997, p. 286). 
Logo, formas, técnicas e por onde iniciar a valoração são sabidas, o que precisa ser realizado é o uso desses elementos.

Apesar de estar em uma pequena parte da Amazônia, a Guiana Francesa, ponto de análise do artigo, tem $90 \%$ de seu território dentro da região da floresta e faz uso de SEs fornecidos, desconsiderados o planejamento e o usufruto da floresta.

\subsection{Guiana Francesa}

A Guiana Francesa é um departamento da França Ultramarina, tendo o menor território da América do Sul com $84 \mathrm{mil} \mathrm{km}^{2}$, o que a configura como o menor país sul-americano, porém, o maior departamento francês. Lembrando que a França é um estado unitário e que suas regiōes são subdivididas em 101 departamentos. Destes, cinco estáo em regióes de ultramar, como o caso da Guiana Francesa. Logo, este é o único território não independente da América do Sul e que tem na foz do rio Caiena, sua capital departamental, de mesmo nome (DUARTE, 2016).

Ela pertence ao bioma amazônico, em uma porcentagem de 1,2\% da totalidade da Amazônia, ao passo que o Brasil tem em média 60\% da área (PNUMA; OTCA; CIUP, 2008). Sua formação geológica destaca-se pelo planalto das Guianas, fazendo fronteira com o Brasil, com o Amapá e com o Suriname.

No território da Guiana Francesa, a floresta tropical da Amazônia representa $90 \%$ de sua área, ocupando as terras altas do planalto da Guiana. Sua extensão é de 7,5 milhóes de hectares, sendo a maior área florestada da União Europeia. O restante da área, como é possível perceber ao observar qualquer mapa da regiáo, é composto por ilhas e costa marítima que representam a planície litorânea do território. Ali se localizam as terras férteis da regiấo que compóem $5 \%$ do território. Nessa área, concentra-se a grande maioria da população, que ao todo, segundo dados de 2015, é estimada em 240 mil habitantes, cujo crescimento populacional é em torno de 3,5\% ao ano. O índice de desemprego gira em torno de $20 \%$ e um dos principais problemas enfrentados pelo país é a imigração ilegal, especialmente de brasileiros que realizam garimpo ilegal (DUARTE, 2016).

Segundo Duarte (2016, p. 29) “40\% da população são créoles, descendentes dos negros africanos, $30 \%$ são imigrantes e $10 \%$ são franceses metropolitanos. Os maroons, populaçóes descendentes de escravos fugidos, que formaram comunidades no interior, representam $6 \%$ e os ameríndios são 5\% dos habitantes".

A Guiana Francesa conta com um grande potencial hidrelétrico, em função da abundância hidrográfica, aproximadamente $800 \mathrm{~m}^{3}$ por pessoa (IAEA, 2015). 
Estima-se que tem potencial para 60 instalaçôes hidrelétricas, mas a fonte fundamental de energia são os combustíveis fósseis, responsáveis pela provisão de $43 \%$ da energia consumida (REPUBLIQUE FRANÇAISE, 2011). A regiáo tem uma produção agrícola pequena, que ocupa 25 mil hectares e a pesca é uma atividade econômica relevante, produzindo, inclusive, para exportação.

Os recursos minerais disponíveis no território são ouro, bauxita, estanho, cobre e diamantes - a concentração desses recursos se dá na porção norte e na porção central do departamento. O garimpo ilegal é um dos grandes problemas enfrentados pelo departamento, pois, anualmente, são produzidas oficialmente, de 2,5 a 3 toneladas de ouro, mas as exportaçóes do produto chegam a 9 toneladas. A fiscalização é dificultada pois o acesso ao interior do território é bastante limitado em virtude do relevo e da densa floresta tropical (DUARTE, 2016).

Apesar de seu status de pertencente à União Europeia e, para os índices da América Latina, ter renda per capita alta, já que o PIB do departamento é de 3 bilhôes de euros, e o PIB per capita gira em torno de 14 mil euros (INSEE, 2015), quando comparados com os índices franceses, que giram em torno de 35 mil euros como PIB per capita, está longe de ter índices igualitários ao de seus compatriotas da França continental (FRANÇA, [s.d.]). Tais dados demonstram que, a Guiana tem um PIB muito inferior aos outros departamentos, o que evidencia seu status de simples colônia e não parte real da França. Tal afirmação é corroborada pelo fato de pelo menos $1 / 4$ da populaçáo franco-guianense se encontrar abaixo da linha da pobreza e de o custo de vida ser alto, em razáo, principalmente, da dependência em relação à França metropolitana (INSEE, 2015). A Guiana francesa é inexpressiva politicamente na América do Sul e periférica para o Estado Francês, mas ainda representa a permanência europeia na América Latina.

Sua história se inicia com a busca da França monárquica ao competir politicamente por províncias, em que já figuravam Inglaterra, Portugal e Espanha, buscando, assim, interferir no Tratado de Tordesilhas. Apelidada de Costa selvagem pelos primeiros navegantes que por ali passaram, por causa de seu clima e de sua geografia, ganhou novo apelido ao ser ocupada, infer vert (inferno verde). Apelido pejorativo e de valoração negativa que recebeu por causa da ocupação infrutífera de Kourou, em 1764. Nesse evento, mais de 11 mil franceses migraram para Kourou, a oeste de Caiena, os quais morreram, em sua grande maioria, por doenças tropicais. Do total, apenas cerca de 60 famílias sobreviveram e foram transferidas para as Îles du Salut, para que pudessem ficar em quarentena antes de retornarem à França metropolitana (PIANTONI, 2009).

A colonização francesa, segundo Iuri Cavlak (2016), encontrou 30 mil ameríndios, população a que nomearam civilizaçấo da mandioca, para contrapor à 
civilização do oriente, conhecida como a civilização do chá. Foi uma colonização de difícil assentamento, sendo a primeira expedição realizada em 1604. Depois 1626, 1628 e 1630, momento em que os colonos não resistiram às diversas adversidades naturais, à relação difícil com a população de ameríndios ou com outros povos europeus ali presentes. O mesmo ocorreu em 1652, 1657 e 1665, quando holandeses expulsaram os franceses de Caiena e estes, no mesmo ano, recuperaram sua posse colonial sob comando de Colbert (CAVLAK, 2016).

Segundo Duarte (2016), que em seus estudos apresenta a história da Guiana Francesa, em 1676, finalmente os colonos franceses conseguiram se estabelecer no território, criando uma colônia francesa.

No período da Revoluçáo Francesa, a Guiana era chamada de guilhotina seca e, no período napoleônico, ganhou o status de local de exílio para envio dos opositores ao regime, que morreram, em sua grande maioria, de fome e doenças tropicais.

Após o fim das guerras napoleônicas na $1^{\circ}$ metade do século XIX, a colônia apresentou um desenvolvimento agrícola consistente, utilizando-se de mão de obra escrava. Com a abolição da escravidão no final do século XIX, houve colapso econômico por falta de mão de obra. A segunda metade do século XIX foi marcada, também, por se tornar uma colônia penal com diversos presídios, chegando a ter 68 mil degredados realizando trabalhos forçados. Inicia-se nesse período o garimpo na regiáo, especialmente de ouro, que teve seu apogeu na década de 1930.

Em 1946, com o processo de departamentalização francês e o fechamento das prisôes - cujos presos foram repatriados -, a Guiana ganha o status de departamento, de maneira que o sistema político seria o mesmo da França, com exceçóes apenas criadas em lei, gerando uma esperança de desenvolvimento econômico e social na comunidade franco-guianense, que não se efetivou na realidade.

Em 1968 foi criado o Centro Espacial de Kourou - em virtude de sua localizaçáo privilegiada que apresenta menos gravidade, por ser próximo à linha do Equador -, que em 1973 passou a compor a Agência Espacial Europeia. Dessa base saiu, em 1980, o frutífero programa espacial de lançamento de satélites Ariane, que muda o estigma de inferno verde da Guiana. Apesar de na década de 1990 apresentar-se como próspera, graças ao capital movimentado pelo Centro Espacial, a Guiana se demonstrava extremamente depende da França metropolitana. Em 2016 houve uma mudança no estatuto departamental, mas até hoje nunca foi cogitada sua independência.

A Guiana apresenta, segundo dados de INSEE (2015), 20\% de desemprego e boa parte de seu PIB é vinculado à estação espacial e à mineração, principalmente a ilegal, como visto acima. 
Segundo dados do relatório Stratégie Nationale pour la Biodiversité (SNB Estratégia Nacional pela biodiversidade - REPUBLIQUE FRANÇAISE, 2014), como meio de concretização da participação francesa na Convenção de Biodiversidade, a La Stratégie Nationale de Développement Durable (SNDD - Estratégia Nacional de Desenvolvimento Sustentável), a 10 SNB determinou que ocorresse até 2010 e reafirmou com a 2a SNB 2011-2020, a busca pelo engajamento dos diversos atores franceses, inclusive na Guiana, para realizar objetivos com esforços concentrados para o cumprimento da Convenção. Para esse departamento foram dadas orientaçôes estratégicas simplificadas em (REPUBLIQUE FRANÇAISE, 2014):

- incentivar o desejo de agir pela biodiversidade;

- preservar os seres vivos e sua capacidade de evoluir;

- investir em um bem comum, o capital ecológico;

- garantir o uso sustentável e equitativo da biodiversidade;

- garantir a coerência da política e eficácia da ação;

- desenvolver, compartilhar e aprimorar conhecimentos.

Tais resoluçôes fazem parte de uma estratégia política muito importante, pois a Guiana apresenta segundo Republique Française (2011), 217 espécies de mamíferos - sendo $11 \%$ endêmicos, 301 espécies de repteis e anfíbios, sendo $9 \%$ dos repteis e $35 \%$ dos anfíbios endêmicos, 691 espécies de aves e 500 espécies de peixe, incluindo os de água doce e do mar; e uma diversidade entre 1500 a 1700 espécies de árvores. Tendo por base os dados europeus, a Guiana francesa tem 45 vezes a quantidade de vertebrados da Europa inteira, demonstrando sua importância em participar consistentemente dos SEs da Amazônia e da Europa.

Em 2007, foi criado o Parque Amazônico da Guiana, com um território de 3,4 milhóes de hectares, ele cobre $40 \%$ do território guianense e faz fronteira com o parque nacional montanhas do Tumucumaque no Brasil. O parque busca preservar o patrimônio natural e cultural de comunidades ameríndias que ali vivem, como os Wayana, Wayapi e Teko, os Alujus, entre outras (REPUBLIQUE FRANÇAISE, 2011).

Apesar de todo esse quadro, a França não tem sido um grande exemplo, por meio da Guiana, quando pensamos nos termos de proteção ambiental, apesar de suas críticas severas à política brasileira. O Consuetudinário Grande Conselho dos Povos Ameríndios denunciou Macron pela atribuiçâo de 360 mil hectares de floresta a mineradoras multinacionais da Guiana (BERROD; LIVONNIÈRE; ALEXANDRE, 2019). O governo francês se defendeu, garantindo que os contratos de extração frequentemente exigem que as árvores sejam replantadas, "mas isso não resolve o problema porque não substituímos uma floresta primária, que levaria 
milênios para encontrar sua riqueza biológica. Por isso a Amazônia é tão importante", lamenta Matthieu Orphelin (BERROD; LIVONNIÈRE; ALEXANDRE, 2019).

O argumento do governo francês para essa política é controlar a atividade ilegal. Segundo Bercy (apud BERROD; LIVONNIÈRE; ALEXANDRE, 2019, $\mathrm{s} / \mathrm{p})$, "porque a atividade ilegal é um verdadeiro flagelo para a Guiana e muito prejudicial ao meio ambiente. Trata-se de pelo menos 10.000 trabalhadores clandestinos, de acordo com um relatório do Institut d'Émission d'Outre-mer (IEOM - Instituto de Emissão Ultramarino). Sem controle, as fazendas costumam poluir muito o solo e os rios".

Apesar da agricultura de subsistência, pesca e várias pesquisas e estudos franceses em relação à floresta amazônica guianesa, ainda não existe uma real política vinculada ao SE, para que $90 \%$ de áreas amazônicas da Guiana forneçam e possam ensejar pagamentos.

\subsection{Guiana Francesa, desenvolvimento sustentável e pagamentos por $\mathrm{SE}$}

Depois da apresentação de todos esses dados, é possível perceber o baixo valor de inserção do departamento da Guiana na política francesa. Apesar de, como apresentado, exigir políticas rígidas dos outros países pertencentes à regiáo amazônica, a França não implementa políticas ambientais reais em seu território. $\mathrm{Na}$ verdade, incentiva, como demonstrado, políticas colonialistas, como extração mineral e dependência da França metropolitana, mas não iguala o departamento ultramarino aos departamentos em território europeu.

O estudo real dos SEs na Guiana Francesa poderia apresentar todo o potencial do departamento, que com os dados apresentados, já são claros. $\mathrm{O}$ uso das PSEs poderia vir a ser a solução para acabar com a pobreza na região, pois há uma grande porçâo da comunidade guianense que está abaixo da linha de pobreza, situação impensável na França Metropolitana, tal beneficiamento também poderia gerar um novo mercado e reduzir o índice de $20 \%$ de desemprego.

Tudo depende de uma política pública real para essa comunidade, que supere políticas rasas ou generalistas, cujo objetivo é garantir o domínio do local. Políticas bem pensadas são sempre necessárias, pois mesmo que se insira os pagamentos por SEs, se não forem bem conectadas com a realidade local, segundo Lauran, Leménager e Aoubid, (2011, p. 42):

[...] correm o risco de marginalizá-los ainda mais dentro de suas próprias comunidades, introduzindo métodos de pagamento 
injustos ou excluindo-os. Sob tais condiçôes, os sistemas de PSA podem sofrer com o aumento de disputas por recursos ou atividades ilícitas decorrentes da exclusão de grandes segmentos da população.

Especialmente, no que se refere aos grupos mais vulneráveis como mulheres, minorias e grupos indígenas.

As comunidades devem ser inseridas, não apenas consultadas, no processo econômico, especialmente dos SEs, pois isso geraria uma mudança na relação com a natureza em si, especialmente no sentido econômico, já que, nos dias atuais, a mineração é uma das atividades mais importantes e incentivada pelo governo francês, como é sabido, de maneira altamente degradadora.

O retorno desse uso não pode ser apenas o reflorestamento, como proposto pelo governo, mas o real pagamento pela destruição dos elementos que geravam SEs. Outro ponto importante é o incentivo ao uso desses serviços de modo a produzir divisas para o departamento, como, por exemplo, o mercado de produtos paisagísticos, valorizando a cultura local. Ou mesmo, o uso recreativo da floresta por meio do turismo ecológico e do incentivo à manutenção de SEs, efetivando o real desenvolvimento do departamento francês de maneira sustentada e sustentável.

\section{Conclusão}

A Amazônia é uma das maiores áreas florestais no planeta e exerce uma função essencial na manutenção da vida dos seres vivos e dos seres humanos, sendo sua proteção necessária para o planeta. Ela representa um ecossistema pouco explorado, ao considerar-se seu tamanho, há muito a ser reconhecido. É dado que a regiáo contribui para a vida no planeta e que tem potencial para cooperar com as atividades econômicas, desde que estratégias sejam traçadas corretamente, pois seus SEs se enquadram em todos os tipos de mercados apresentados.

Os pagamentos por SEs apenas iniciam sua inserção na realidade, mas como visto, têm muito a oferecer. Estudos são implementados para sua implantação, mas sempre são pensados e analisados nos países que ocupam a maior parte da Amazônia, como Brasil e Peru. Entretanto, a Guiana Francesa, departamento francês, tem muito a oferecer, pois $90 \%$ de seu território é recoberto pelo bioma amazônico, que ainda está pouco explorado, haja vista as dificuldades e a limitação de circulação.

O departamento da Guiana Francesa, apesar de parte da França, não vem sendo tratado em igualdade com os departamentos franceses presentes no 
continente europeu, e pelos dados apresentados, é possível classificá-la com uma realidade de colônia. A região apresenta pobreza, característica não presente nos outros departamentos, além de uma dependência da França metropolitana muito grande. Sua economia se baseia em pesca e extraçáo mineral e, mesmo tendo o Parque Amazônico da Guiana sido instituído em 2007, não há uma política ambiental que pense em explorar a região de maneira ambientalmente adequada, no sentido de proteger seus SEs e garantir os pagamentos por estes, de maneira consistente.

É necessário que a Guiana Francesa efetivamente se reconheça como parte da Amazônia e se insira nas políticas para sua proteçáo e usos ambientalmente adequados. Se inserindo nos debates, pesquisas e implantação de políticas, compreendendo-se como parte importante no processo, e que tem um papel ainda mais importante que os outros países a desempenhar, por ser parte da União Europeia. Por esse simples fato, deveria ser o exemplo a ser seguido e náo se apartar da interação com os outros países pertencentes à Amazônia. A França deve, em seus departamentos, seguir o caminho do desenvolvimento sustentável, como princípio de igualdade entre seus cidadãos, considerando os direitos da comunidade lá existente. Isso tudo deve ser realizado pela mediação da PSE, para a qual tem feição e disponibilidade de recursos, a serem inseridos nos diversos mercados indicados neste artigo. Fato que pode ser levado a cabo por esse departamento pertencer a um dos maiores mercados que deve pagar pela PSE, a Uniáo Europeia.

\section{Referências}

ANDRADE, D. C.; ROMEIRO, A. R. Serviços ecossistêmicos e sua importância para o sistema econômico e o bem-estar humano. Campinas: UNICAMP, 2009. Disponível em: http://www.avesmarinhas.com.br/Servi\%C3\%A7os\%20ecossist\%C3\%AAmicos\%20e\%20sua\%20import $\%$ C3\%A2ncia $\% 20$ econ $\%$ C3\%B 4 mica. pdf. Acesso em: 25 out. 2020.

ARAÚJO, I. S. Identificação e valoração de serviços ecossistêmicos no Parque Das Dunas, NATAL - RN. Dissertação (mestrado). Programa de Pós-Graduação e Pesquisa em Geografia (PPGE), Universidade Federal do Rio Grande do Norte, Natal, 2018. Disponível em: https://repositorio.ufrn.br/handle/123456789/25406. Acesso em: 25 out. 2020.

BERROD, N.; LIVONNIÈRE, S.; ALEXANDRE, V. Amazonie: la France estelle bien placée pour faire la leçon au Brésil? LeParisien, 27 ago. 2019. Disponível em: https:/www.leparisien.fr/environnement/amazonie-la-france-est-elle-bien-placee-pour-faire-la-lecon-au-bresil-26-08-2019-8139561.php. Acesso em: 25 out. 2020 . 
CAMPANHA, M. M. et al. Serviços ecossistêmicos: histórico e evolução. In: FERRAZ, R. P. D. et al. Marco referencial em serviços ecossistêmicos. Brasília, DF: Embrapa, 2019. p. 38-54. Disponível em: https://ainfo.cnptia.embrapa.br/digital/ bitstream/item/205733/1/Marco-Referencial-em-Servicos-Ecossistemicos-2019. pdf. Acesso em: 25 out. 2020.

CAVLAK, I. Em torno das origens da Guiana Francesa: dos primórdios ao século XIX Revista Eletrônica de Humanidades do Curso de Ciências Sociais da UNIFAP, Macapá, v. 9, n. 3, p. 63-71, dez. 2016. Disponível em: https://periodicos.unifap. br/index.php/pracs. Acesso em: 25 out. 2020.

CMED - COMISSÃO MUNDIAL SOBRE MEIO AMBIENTE E DESENVOLVIMENTO. Nosso futuro comum. 2. ed. Rio de Janeiro: Fundação Getúlio Vargas, 1991.

COSTA, B. S.; OLIVEIRA, M. L. Florestas plantadas de eucalipto no Brasil: uma cultura nociva aos recursos hídricos? Veredas do Direito, Belo Horizonte, v. 16, n. 36, p. 123-141, set./dez. 2019. Disponível em: http:// www.domhelder.edu.br/ revista/index.php/veredas/article/view/1671. Acesso em: 25/ out. 2020.

COSTANZA, R. et al. Modeling complex ecological economic systems: toward an evolutionary dynamic understanding of people and nature. BioScience, n. 43, p. $545-555,1993$.

COSTANZA, R.; et al. Changes in the global value of ecosystem services. Global Environmental Change, v. 26, p. 152-158, may 2014. Disponível em: https:// www.researchgate.net/publication/262489570_Changes_in_the_global_value_ of_ecosystem_services. Acesso em: 25 out. 2020.

CUSTÓDIO, M. M. A importância da valorização econômica na proteção jurídica do meio ambiente. v. 1. Rio de Janeiro: Lumen Iuris, 2016. p. 228.

DUARTE, G. R. Guiana Francesa: uma análise geohistórica. Revista Franco-Brasileira de Geografia, Confins, n. 28, set. 2016. Disponível em: http://journals.openedition.org/confins/11072. Acesso em: 25 out. 2020.

ELOY, L.; COUDEL, E.; TONI, F. implementando pagamentos por serviços ambientais no Brasil: caminhos para uma reflexáo crítica. Sustentabilidade em Debate, Brasília, DF, v. 4, n. 1, p. 21-42, 2013. Disponível em: https://periodicos.unb.br/ index.php/sust/article/view/15541. Acesso em: 25 out. 2020.

ETRILLARD, C. Paiements pour services environnementaux: nouveaux instruments de politiquepublique environnementale. Développement Durable et 
Territoires, v. 7, n. 1, avr. 2016. Disponível em: http://journals.openedition.org/ developpementdurable/11274. Acesso em: 25 out. 2020.

FERRAZ, R. P. D. et al. (ed). Marco referencial em serviços ecossistêmicos. Brasília, DF: Embrapa, 2019. Disponível em: https://ainfo.cnptia.embrapa.br/digital/bitstream/item/205733/1/Marco-Referencial-em-Servicos-Ecossistemicos-2019.pdf. Acesso em: 25 out. 2020.

FRANÇA - PIB. Countryeconomy.com. Disponível em: https://pt.countryeconomy.com/governo/pib/franca. Acesso em: 25 out. 2020.

FREITAS, J. Sustentabilidade: direito ao futuro. Belo Horizonte: Fórum, 2011.

GAUDERETO, G. L. et al. Avaliação de serviços ecossistêmicos na gestão de áreas verdes urbanas: promovendo cidades saudáveis e sustentáveis. Ambiente \& Sociedade, São Paulo, v. 21, 2018. Disponível em: https://www.scielo.br/scielo.php?script=sci_arttext\&pid=S1414=753-2018000100410X\&lng=pt\&nrm=iso\&tlngpt. Acesso em: 25 out. 2020.

IAEA - INTERNATIONAL ATOMIC ENERGY AGENCY. Features: world water needs. Disponível em: http://www.iaea.org/newscenter/features/water/index.shtml. Acesso em: 25 out. 2020.

IDSM - INSTITUTO DE DESENVOLVIMENTO SUSTENTÁVEL MAMIRAUÁ. Conteúdo Especial Amazônia. Tefé: IDSM, [s.d.]. Disponível em: https:// www.mamiraua.org.br/pdf/b835ab4918934c68328ea188943e86b0.pdf. Acesso em: 25 out. 2020 .

INSEE - INSTITUT NATIONAL DE LA STATISTIQUE ET DES ÉTUDES ÉCONOMIQUE. Guyane. Disponível em: http://www.insee.fr/regions/guyane/. Acesso em: 25 out. 2020.

KITAMURA, P. C. Amazônia: produtos e serviços naturais e as perspectivas para o desenvolvimento sustentável regional. In: ROMEIRO, A. R.; REYDON, B. P.; LEONARDI, M. L. A. (orgs.). Economia do meio ambiente. Campinas: UNICAMP, 1997. p. 283-298.

LAURAN, Y. S.; LEMÉNAGER, T.; AOUBID, S. Les paiements pour services environnementaux: de la théorie à la mise en oeuvre, quelles perspectives dans les pays en développement? Paris: AFD, 2011. Disponível em: https://www.afd.fr/fr/ ressources/les-paiements-pour-services-environnementaux-de-la-theorie-la-mise-en-oeuvre-quelles-perspectives-dans-les-pays-en-developpement. Acesso em: 25 out. 2020. 
LEVIN, S. A. Ecosystems and the biosphere as complex adaptive systems. Ecosystems, v. 1, p. 431-436, 1998. Disponível em: https://link.springer.com/article/10.1007/s100219900037. Acesso em: 25 out. 2020.

MARCO, C. M.; MEZZAROBA, O. O direito humano ao desenvolvimento sustentável: contornos históricos e conceituais. Veredas do Direito, Belo Horizonte, v. 14, n. 29, p. 232-349, maio/ago. 2017. Disponível em: http://revista.domhelder. edu.br/index.php/veredas/article/view/1066. Acesso em: 25 out. 2020.

MARENGO, J. Mudanças climáticas globais e seus efeitos sobre a biodiversidade: caracterização do clima atual e definição das alteraçôes para o território brasileiro ao longo do século XXI. Brasília, DF: Ministério do Meio Ambiente \& Secretaria de Biodiversidade e Florestas, 2006. Disponível em: http://www.dca.iag.usp.br/ relatorios/ambrizzi/livro/livro\%20completo.pdf. Acesso em: 25 out. 2020.

MAYRAND, K.; PAQUIN, M. Le paiement pour les services environnementaux: étude et évaluation des systèmes actuels. Montreal: Unisféra International Centre, 2004. Disponível em: http://www3.cec.org/islandora/fr/item/2171-payments-environmental-services-survey-and-assessment-current-schemes-fr.pdf. Acesso em: 25 out. 2020.

MEA - MILLENNIUM ECOSYSTEM ASSESSMENT. Ecosystems and human well-being:synthesis. Washington, DC: Island Press, 2005. Disponível em: https:// www.millenniumassessment.org/document[s.d.]ocument.356.aspx.pdf. Acesso em: 25 out. 2020.

MILARÉ, E. Direito do Ambiente. 10. ed. rev. atual e ampl. São Paulo: RT, 2015. NOGUEIRA, J. M.; MEDEIROS, M. A. A.; ARRUDA, F. S. T. Valoração econômica do meio ambiente: ciência ou empiricismo? Cadernos de Ciência e Tecnologia, Brasília, DF, v. 17, n. 2, p. 81-115, maio/ago. 2000. Disponível em: https:// seer.sct.embrapa.br/index.php/cct/article/viewFile/8870/4995. Acesso em: 25 out. 2020 .

NOGUEIRA, J. M.; MELLO, M. B. Economia e Direito: interfaces no tratamento da problemática ambiental. In: II CONGRESSO NACIONAL DE DIREITO AMBIENTAL DA OAB, 2., 2003, Belo Horizonte. Anais [...]. Belo Horizonte: OAB, 2003.

ORTIZ, R. A. Valoração econômica ambiental. In: MAY, P.; LUSTOSA, M. C.; VINHA, V. (orgs.). Economia do meio ambiente: teoria e prática. Rio de Janeiro: Elsevier, 2003. 
PAGIOLA, S.; VON GLEHN, H. C.; TAFFARELLO, D. (orgs.). Experiências de pagamentos por serviços ambientais no Brasil. São Paulo: SMA/CBRN, 2013. Disponível em: http://documents.worldbank.org/curated/en/548371468021548454/ pdf/864940WP0P088000PORTUGUESE0PSAlivro.pdf. Acesso em: 25 out. 2020.

PIANTONI, F. L'enjeu migratoire em Guyane Française. Matoury: Ibis Rouge, 2009.

PNUMA - PROGRAMA DAS NAÇÓES UNIDAS PARA O MEIO AMBIENTE; OTCA - ORGANIZAÇÃO DO TRATADO DE COOPERAÇÃO AMAZÔNICA; CIUP - CENTRO DE PESQUISA DA UNIVERSIDAD DEL PACIFICO. Geo Amazônia: perspectivas do meio ambiente na Amazônia. Brasília, DF, 2008.

POFFO, I. R. F. Vazamentos de óleo no litoral norte do estado de São Paulo: análise histórica (1974-1999). In: ABRAMOVAY, R. (org.). Construindo a ciência ambiental. São Paulo: Annablume, 2002.

REPUBLIQUE FRANÇAISE. Actions en faveur de la biodiversité en Guyane. Direction de l'Environnement, de l'Aménagement et du Logement. Guiana: CCpr imprimerie, jun de 2011. Disponível em: http://www.guyane.developpement-durable.gouv.fr/IMG/pdf/Livret_actions_en_faveur_biodiversite.pdf Acesso em: 25 out. de 2020

REPUBLIQUE FRANÇAISE. La stratégie nationale pour la biodiversité: un engagement. Le cinquième rapport national de la France à la Convention sur la Diversité Biologique. Ministère de l'Écologie, du Développement durable et de l'Énergie. Paris: Citizen Press, oct. 2014. Disponível em: http://www.guyane.developpement-durable.gouv.fr/IMG/pdf/SNB_2011-2020.pdf. Acesso em: 25 out. 2020.

SANTOS, R. M. Serviços ecossistêmicos: a relação com o setor florestal. Trabalho de Conclusão de Curso (Graduação) - Faculdade de Tecnologia, Departamento de Engenharia Florestal. Universidade de Brasília, Brasília, DF, 2015. Disponível em: https://bdm.unb.br/bitstream/10483/11132/1/2015_RenataMedeirosDosSantos.pdf. Acesso em: 25 out. 2020.

SANTOS, D.; CUSTÓDIO, M. M. Valoração econômica da paisagem: proposição de discussão. Revista Eletrônica de Direito do Centro Universitário Newton Paiva, Belo Horizonte, n. 19, p. 153-156, 2012. Disponível em: https://revistas. newtonpaiva.br/redcunp/wp-content/uploads/2020/05/D19-15.pdf. Acesso em: 25 out. 2020 . 
SANTOS, R. F. O contexto histórico da definiçẫo conceitual de serviços ecossistêmicos. In: VI SIMPÓSIO DA CIÊNCIA DO AGRONEGÓCIO - CIENAGRO, 6., 2018, Porto Alegre. Anais [...]. Porto Alegre, UFRGS, 2018. Disponível em: https://www.ufrgs.br/cienagro/wp-content/uploads/2018/10/O-contexto-hist\%C3\%B3rico-da-defini\%C3\%A7\%C3\%A3o-conceitual-dos-servi\%C3\%A7os-ecossist\%C3\%AAmicos-Rozely-F-Santos.pdf. Acesso em: 25 out. 2020.

SAWYER, D. População e desenvolvimento sustentável na Amazônia. Brasília, DF: UNFPA, 2014. Disponível em: https://brazil.unfpa.org/site[s.d.]efault/files/pub-pdf/amazonia1.pdf. Acesso em: 25 out. 2020.

SILVA, R. F. T. Manual de Direito Ambiental. Salvador: Juspodium, 2015.

SOUZA, C. A. et al. Environmental services associated with the reclamation of areas degraded by mining: potential for payments for environmental services. Ambiente \& Sociedade, São Paulo, v. 19, n. 2, p. 137-168, 2016. Disponível em: https://www.scielo.br/scielo.php?pid=S1414-753X2016000200137\&script=sci_abstract. Acesso em: 25 out. 2020. 